\title{
PRELIMINARY STUDIES ABOUT KNOWLEDGE AND APPLICATIONS OF SCIENCE MNEMONICS BY POLISH PUPILS
}

\section{BADANIA PILOTAŻOWE O WIEDZY I STOSOWANIU MNEMONIK Z PRZEDMIOTÓW ŚCISŁYCH PRZEZ POLSKICH UCZNIÓW}

\begin{abstract}
Mnemonic devices are specific ways, which during coding new information apply known elements for improving subsequent access to that information in the memory. Consequently, not much is known about techniques for optimizing recall performance with mnemonic devices or the suitability of using mnemonic devices in educational applications. Moreover, in literature there are a lot of examples in chemistry, biology, physics and mathematics mnemonics approaches, however in the related literature, there is a lack of current and reliable studies for this subject. In this original work we describe mnemonic methods from this point of view in the learning and teachings of science subjects. A large trumps of this article is the demonstration of the old well-known method of the learning/teaching in the new scene. This is the first article in literature that present actual data about this topic according to learning and studying the science subjects by memonic studies.
\end{abstract}

Keywords: mnemonics, mnemonic methods, mnemonic devices, memorizing methods, science subjects

\section{Introduction}

The word mnemonic derives from the Greek goddess of memory - Mnemosyne, and means "memory enhancing". Mnemonic ("nee-moh-nick") techniques, also called a mnemonic strategies, mnemonic devices, or mnemonics, are systematic procedures designed to improve one's memory [1]. Hence, mnemonics strategies ought to be understood as systematic procedures for intensification a memory. The main idea of mnemonic strategies is application in developing better ways to encode (take in) information, so that it will be much easier to retrieve (remember) [2]. Therefore, mnemonic

\footnotetext{
${ }^{1}$ The Toxicological and Pharmaceutical Analysis Group, Department of Analytical Chemistry, Faculty of Chemistry, Jagiellonian University in Kraków, ul. R. Ingardena 3, 30-060 Kraków, Poland, email: jurowski@chemia.uj.edu.pl

${ }^{2}$ The Coordination Chemistry Group, Department of Inorganic Chemistry, Faculty of Chemistry, Jagiellonian University in Kraków, ul. R. Ingardena 3, 30-060 Kraków, Poland, email: jurowska@ chemia.uj.edu.pl

${ }^{3}$ Department of Chemical Education, Faculty of Chemistry, Jagiellonian University in Kraków, ul. R. Ingardena 3, 30-060 Kraków, Poland, fax +48 126340 515, email: krzeczko@ chemia.uj.edu.pl

${ }^{4}$ Secondary School No. 6, ul. Wąska 7, 31-057 Kraków, Poland, email: krzeczko@chemia.uj.edu.pl

${ }^{*}$ Corresponding author: krzeczko@chemia.uj.edu.pl
} 
devices can be attended as learning strategies which can often enhance the learning and later recall of information [3]. The main task in developing mnemonic strategies is to find a way to connect new information to information students already have locked in long-term memory. If pupils or students make an enough strong connection, the memory will last a very long time, because the mnemonic strategy had carefully linked it to things that will be very familiar according to these procedures can be extraordinarily effective [2]. Moreover, the mnemonic strategies can be incorporated for the elements that require recall, what is both advantage and disadvantage of this method. These methods are also useful way of improving memory in students who exhibit difficulty remembering things. Hence, the mnemonic devices do not represent an educational panacea but can be an important component in improving memory and learning or teaching process.

Mnemonic methods are unlikely to benefit memory in skilled everyday activities, however, where memory encoding must be task specific and appropriate for the relevant tasks [4]. During skilled everyday activity information needs to be encoded to allow direct access to domain-specific knowledge necessary to complete the task [5]. It is proper to pay attention, that these methods have a wide applications in problems connected with the memory of older persons eg remembering of the shopping list, face-name association learning $[6,7]$.

From education point of view, many sources evidence that pupils and student who are using mnemonics method also perform better on comprehension tests (eg [8-10]). Moreover, using of mnemonic devices often results in very high levels of recall performance. These methods operate by the use of cognitive structures, but on the other hand these methods are characterized by low or lack of relation to the conceptual content of the material being learned and also they are focused only on certain aspects of their operation [3].

Overall, the mnemonic devices are not teaching methods. It was also proved that mnemonic strategies can be used to enhance science learning when the curriculum involves a lecture, textbook format $[2,11]$, or when the curriculum involves a hands-on, inquiry learning format. However, in spite of many advantages it is possible to obtain a wrong conclusion that mnemonic devices inhibit comprehension [12]. In turn, the mnemonic methods are very good way to understanding science in school but in academic content those strategies may be an important instructional component [2]. It was observed also that, when students generate their own strategies, instruction may proceed at a much slower rate and students' performances may be lower than when teachers supply the strategies [11]. On the other hand, some studies indicated that students who have been taught strategies for creating their own mnemonics outperform comparison students in free-study conditions. This problem can be summarized that, everyone needs individual developed strategy, but it seems that combination of student-generated and teacher created mnemonic strategies is the best way.

\section{Materials and methods}

Are students of Upper Secondary Schools in Poland know and use mnemonic methods in school practice? If they use, are they use these methods consciously? These and many other questions were an inspiration to the undertaking this research by authors of this article. 


\section{Appendix 1.}

Questionnaire about methods of remembering and memorizing the information

Complete the questionnaire writing suitable answers. Questionnaire is anonymous, the results will become used in scientific article. After the mark of the answer do not return to previous questions(!)

1. Your gender and (Place an ' $X$ ' in appropriate box): $\square$ Male / $\square$ Female

2. I am ...... years old and my race/ethnicity is (Place an 'X' in appropriate box): $\square$ European $I \square$ Asian $I \square$ Other 3. 1. Do you know what are mnemonic devices/methods? (Place an ' $X$ ' in appropriate box): $\square$ Yes $\quad$, $\square$ No

3. 2. If You choice "Yes" in question 3.1, explain in Your own word what are?

Below are presented different types of mnemonic methods with examples. Do you know some of them? (Place an ' $\mathrm{X}$ ' in appropriate boxles or leave empty fields)

$\square$ Rhyme - a rhyme is a poem or verse that uses words that end with the same sound; e.g. Twinkie, winkle little sta

circumference is 2 pir

I didn't really know you cared area is pir squared.

$\square$ Acronym - an acronym is a word that can be pronounced that is made by using the first letter of other words; e.g. $\underline{\text { CARO }}$ - Cathode Anode Reduction $\underline{\text { Oxidation. }}$

$\square$ Abbreviation - an abbreviation is a group of letters made from the first letter of each word to be remembered; e. $\mathbf{A}$. ABC for remember the most important acts of the first-aid A - Airways, B - breath, C - circulation.

$\square$ Acrostic - an acrostic sentence or phrase is formed by words beginning with the first letter of each word to be remembered; e.g. All Altruists Gladly Make Gum In Gallon Tanks for remember the aldohexoses Allose, Altrose, Glucose, Mannose Fructose, Gulose, Idose, Galactose Talose.

$\square$ Pegwords - a pegword is a word that helps you remember something by forming a picture in your mind e.g. ROMP: $\mathbf{R}$ - alkyl group, $\mathrm{O}$ - ortho, M-meta and P - para according to below picture

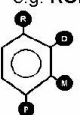

5. Which method most often do you use?

$\square$ Rhyme / $\square$ Acronym I $\square$ Abbreviation I $\square$ Acrostic / $\square$ Pegwords I $\square$ Noone

6. How often you use mnemonic methods during the learning?

$\square$ Never

$\square$ Only when it is given by the teacher

$\square$ Sporadically - mostly when other methods disappoint

$\square$ Always (I use and invent own examples)

$\square$ Other option (write Your option)

7. On what subject did you use examples which can be a mnemonics device? (Place an ' $X$ ' in appropriate box/es or leave empty fields)
$\square$ Biology $f \square$ Chem istry
$\square$ Physics
$\square$ Mathematics
$\square$ none

$\square$ Other (which one?)

8. Give the any example/s being with the mnemonics which most often you use or which best you remember (Use the retreat of the card).

We thank You very much for the participation in this questionnaire!

K. Jurowski, A. Jurowska, M. Krzeczkowska, Facuity of Chemistry, Jagiellonian University in Kraków

Fig. 1. Questionnaire about methods of remembering and memorizing the information

The first experiment was connected with examining general information about knowledge, popularity, the consciousness and practical approach of mnemonics devices 
according to learning chemistry, biology, physics and mathematics. Moreover, we wanted to find out how which pupils (by gender, age, race/ethnicity) of Upper Secondary Schools in Poland, how use (own, given on the lesson, found in literature etc.), how often and in which circumstances (subjects, topics). In research take part a two public Upper Secondary Schools in Warsaw from full-day state-funded class-rooms.

\section{Materials}

In according to gather information about the mnemonics methods knowledge by students, the appropriate questionnaires about general information were prepared - the Figure 1. Questionnaire covered two categories of information: 1) information about participants (gender, age, race/ethnicity) and 2) their information about the knowledge, application and examples of mnemonic methods.

\section{Appendix 2.}

All of examples from Questionnaire about methods of remembering and memorizing the information are analogous in Polish language - Table 1.

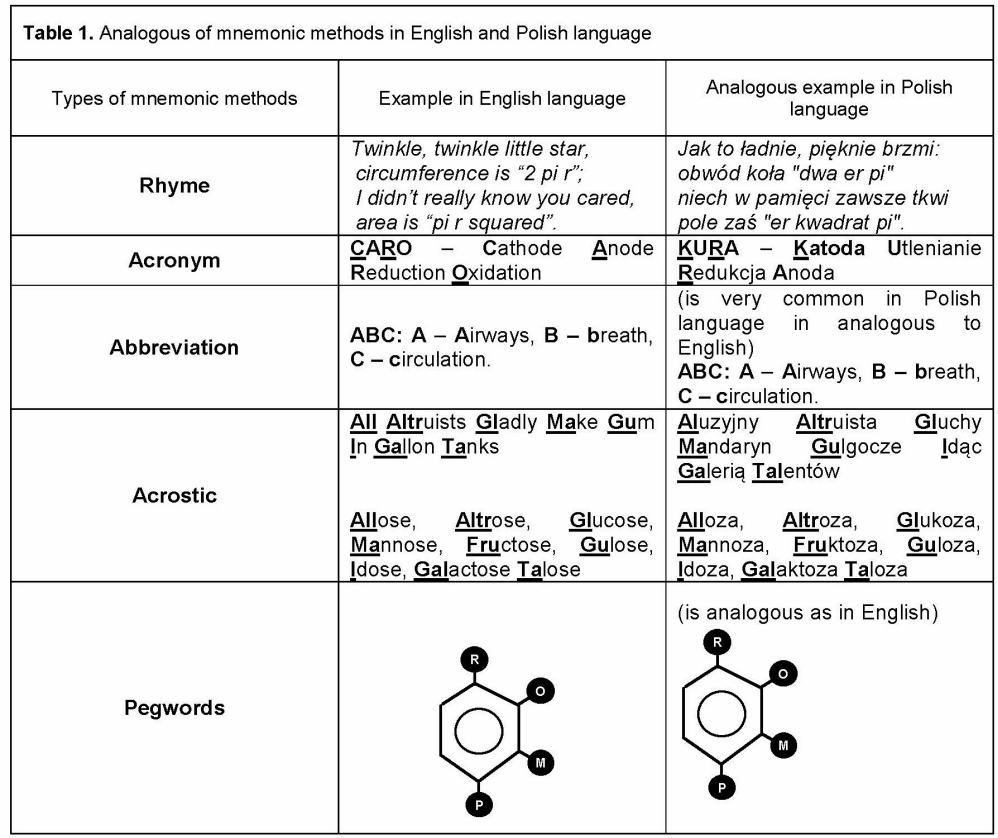

K. Jurowski, A. Jurowska, M. Krzeczkowska, Faculty of Chemistry, Jagiellonian University in Kraków

Fig. 2. All of examples from Questionnaire about methods of remembering and memorizing the information

In questionnaire we focused mostly on:

1) knowledge and the understanding the term "mnemonics method/devices";

2) usages and consciousnesses of the usage of mnemonic methods in learning; 
3) popularities of given methods according to applications and depending on the given subject;

4) giving examples being with the mnemonics which most often students use or which best their remember;

5) connection age, gender and race/ethnicity with mentioned problems (questions 1-4).

Importantly, we include the simple description of each mnemonics method and examples - Figure 2. This was done to ensure that all participants understand all methods ideas and could give the any example/s being with the mnemonics.

\section{Method}

Participants. Participants included 479 students aged: 15-19 years $\left(\mathrm{M}_{\mathrm{age}}=17.48\right.$ years; $\left.\mathrm{SD}=1.8\right)$. All investigated students come from the two public Upper Secondary Schools from full-day state-funded class-rooms in Warszawa (capital of Poland).

Students characteristics, by conditions

\begin{tabular}{|c|c|c|c|c|c|c|c|c|c|}
\hline Upper Secondary School & \multicolumn{9}{|c|}{ School $1(n=241)$} \\
\hline \multirow[t]{2}{*}{ Level of education } & \multicolumn{3}{|c|}{$\begin{array}{c}1^{\text {st }} \text { classes } \\
n=77\end{array}$} & \multicolumn{3}{|c|}{$\begin{array}{c}2^{\text {nd }} \text { classes } \\
n=81\end{array}$} & \multicolumn{3}{|c|}{$\begin{array}{c}3^{\text {rd }} \text { classes } \\
n=83\end{array}$} \\
\hline & {$[\%]$} & $n$ & Missing $^{\mathrm{a}}$ & [\%] & $n$ & Missing $^{\mathrm{a}}$ & {$[\%]$} & $n$ & Missing $^{\mathrm{a}}$ \\
\hline Gender & & 76 & 1 & & 81 & 0 & & 83 & 0 \\
\hline Male & 48.7 & & & 51 & & & 53 & & \\
\hline Female & 51.3 & & & 49 & & & 47 & & \\
\hline Race/ethnicity & & 75 & 2 & & 83 & 1 & & 79 & 4 \\
\hline European & 90.4 & & & 98.8 & & & 89.3 & & \\
\hline Asian & 5.5 & & & 0 & & & 4.0 & & \\
\hline Other $^{\mathrm{b}}$ & 4.1 & & & 1.2 & & & 6.7 & & \\
\hline Student's Age [years] & & 74 & 0 & & 84 & 0 & & 82 & 1 \\
\hline 15 & 1.3 & & & 0 & & & 0 & & \\
\hline 16 & 93.2 & & & 1.2 & & & 0 & & \\
\hline 17 & 5.5 & & & 94.0 & & & 1.2 & & \\
\hline 18 & 0 & & & 4.8 & & & 97.6 & & \\
\hline 19 & 0 & & & 0 & & & 1.2 & & \\
\hline
\end{tabular}

\begin{tabular}{|c|c|c|c|c|c|c|c|c|c|}
\hline Upper Secondary School & \multicolumn{9}{|c|}{ School $2(n=238)$} \\
\hline \multirow[t]{2}{*}{ Level of education } & \multicolumn{3}{|c|}{$\begin{array}{c}1^{\text {st }} \text { classes } \\
n=81\end{array}$} & \multicolumn{3}{|c|}{$\begin{array}{c}2^{\text {nd }} \text { classes } \\
n=79\end{array}$} & \multicolumn{3}{|c|}{$\begin{array}{c}3^{\text {rd }} \text { classes } \\
n=78\end{array}$} \\
\hline & {$[\%]$} & $n$ & Missing $^{\mathrm{a}}$ & {$[\%]$} & $n$ & Missing $^{\mathrm{a}}$ & {$[\%]$} & $n$ & Missing $^{\mathrm{a}}$ \\
\hline Gender & & 81 & 0 & & 78 & 1 & & 77 & 1 \\
\hline Male & 51.8 & & & 43,6 & & & 53.2 & & \\
\hline Female & 48.2 & & & 56.4 & & & 46.8 & & \\
\hline Race/ethnicity & & 78 & 3 & & 79 & 0 & & 76 & 2 \\
\hline European & 100 & & & 98.8 & & & 92.1 & & \\
\hline Asian & 0 & & & 0.0 & & & 1.3 & & \\
\hline Other $^{b}$ & 0 & & & 1.2 & & & 6.6 & & \\
\hline Student's Age [years] & & 80 & 1 & & 76 & 3 & & 78 & 0 \\
\hline 15 & 2.5 & & & 0 & & & & 0 & \\
\hline 16 & 93.75 & & & 5.5 & & & & 0 & \\
\hline 17 & 3.75 & & & 94.5 & & & & 2.5 & \\
\hline 18 & 0 & & & 0 & & & & 92.4 & \\
\hline 19 & 0 & & & 0 & & & & 5.1 & \\
\hline
\end{tabular}

\footnotetext{
${ }^{\mathrm{a}}$ due to the fact that participant did not mark (empty answer), ${ }^{\mathrm{b}}$ eg national minorities (Jews, Romani people)
} 
Differences in the level of participation are the same due to the fact that in all classes, the same curriculum (program) is applied. We had an approximately number of males and females in each class. In both schools we investigated groups of $1^{\text {st }}-3^{\text {rd }}$ classes.

Before studies, students were asked to complete a questionnaire that included demographic information, such as birth date, gender and ethnicity. Because all participants were fluent in Polish, hence all of them full understand all questions in questionnaire. All participants provided informed consent. Participants were given office supplies gifts as compensation for their involvement. The Table 1 presents all participants characteristics by conditions.

\section{Procedure}

Before the accession to the questionnaire about mnemonics method, all students were informed that their answers were anonymous and results will be published in scientific article. All of the participants filled a questionnaires individually, at school (classrooms) after lessons having the appropriate time on their own answers (approx. the one lesson hour - 45 minutes or more), however they could not use any sources (eg books, phones, internet, own notes etc.) and they could not communicate each other. Few students had a problem with given by them examples - they did not know whether their example can be an example of mnemonic methods. In this situation they consulted their dilemmas with a teacher on personally conversation. Participants were not given solution feedback and were asked not to reveal information about the experiment to others. The research was made in period of September - December in 2014.

\section{Results and discussion}

Do Polish students know what are mnemonics devices/methods?

The data of question 3.1 (Do you know what are mnemonics devices/methods?) according to gender, race/ethnicity, age and from point of all participants are presented in Figure 3.

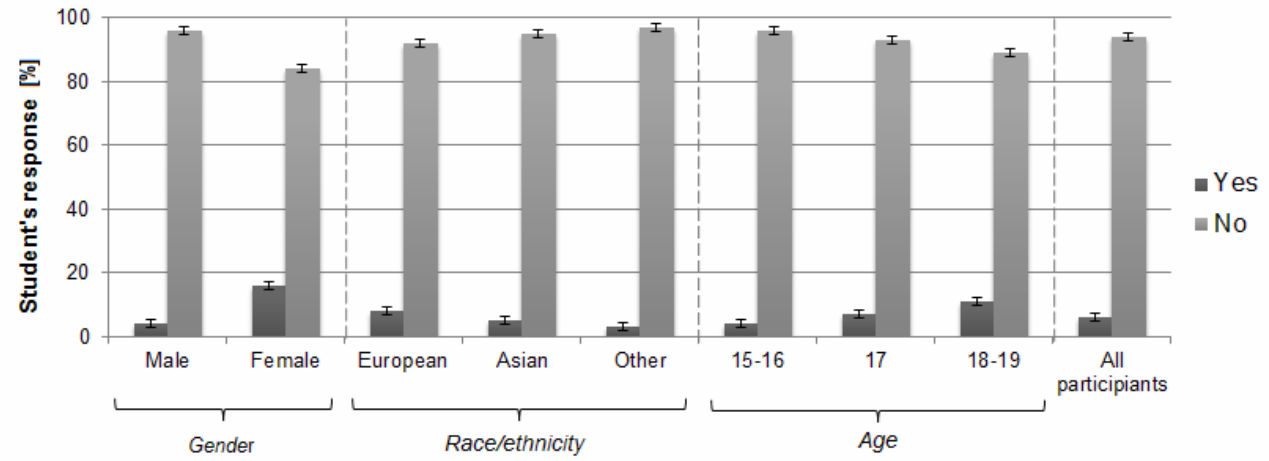

Fig. 3. The student's response of question 3.1 (Do you know what mnemonic devices/methods are?) from questionnaire in experiment 1 by gender, race/ethnicity, age and from point of all participants 
As can be expected, the most of participants (94\% according to all participants) do not know term "mnemonic devices/methods". From the point of view of the gender, this term is known more by female than male (16\% - female, $4 \%$ - male). According to race/ethnicity the results are very similar (8\% - European, 5\% - Asian, 3\% - other). Very interesting results can be gave by research due to the age of participants - the knowledge about the term increases according to the age of students. This can be connected with few aspects: 1) together with the age students recognize the term of mnemonics methods on different subjects; 2) schoolboys together over time find and explore suitable for themselves method for memorization ( $\mathrm{eg}$ they find in the literature - handbooks/internet).

All participants from these that know what are mnemonics methods can also correctly define this term (question 3.2). To most frequent answers were eg "Methods making possible quick memorization", "Manners of easy remembering", "Strategies of the learning and remembering facts", "Very useful methods permitting quickly recall the information from memory", "Useful methods for remembering facts and information".

\section{Do Polish people know some of mnemonic methods/devices?}

The results suggest that the most of students does not know this term. This can be true conclusion, however it can be possible also that students do not know term, but they can know the methods. In other words, students can use in practice some of mnemonics method, but can do this unconsciously - do not know the definition, but can give chosen examples. According to this approach, the question 4 can give appropriate answers for this dilemma. In this question students got also the name, the explanation and the example of the given method. This type of the approach made possible the introduction of students with this problem. The obtained results are presented in Figure 4.

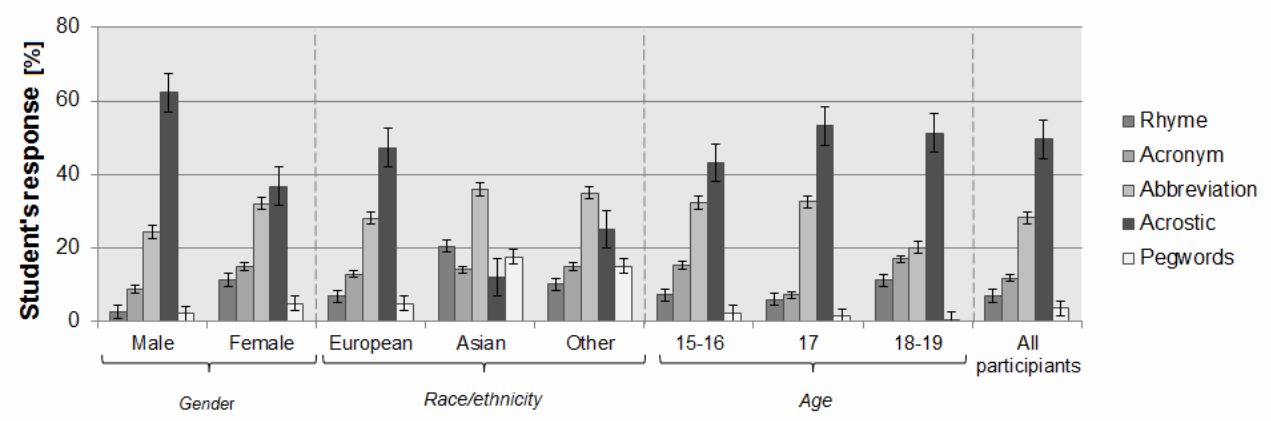

Fig. 4. The student's response of question 4 (Do you know some of mnemonic methods/devices?) from questionnaire in experiment 1 by gender, race/ethnicity, age and from point of all participants

Analysis of results from Figure 2 indicate knowledge about method, according to all participants are the most known methods are - Acrostic (49.55\%) and Abbreviation $(28.2 \%)$. From the point of view of the gender, the most known for female are also Acrostic (36.8\%) and Abbreviation (32.1\%) methods. This observation is also analogous to male, however the Acrostic method is twice more pointed in male according to female $(62.3 \%$ male vs. $36.8 \%$ - female). 
According to race/ethnicity the results are quite different. For European results are very similar to male and female results (Acrostic - 47.3\%, Abbreviation - 28.1\%, Acronym $12.9 \%$, Rhyme $-6.8 \%$ and Pegwords - 4.9\%). For Asian and other nationalities the most known is Abbreviation method (Asian - 14\%, other - 15\%), however second place is different - Rhyme for Asian (20.5\%) and Acrostic for other nationalities (25\%). Other methods are on the comparable level of the popularity for both groups (Asian: Pegwords $17.5 \%$, Acronym - 14\%, Acrostic - 12\%; other nationalities: Pegwords - 15\%, Acronym $15 \%$, Rhyme - $10 \%)$.

The ranking of the knowledge of given methods are the same for all age groups, however, there are changes in their quantitative value.

\section{Which mnemonics method/methods most often do Polish students use?}

The information about knowledge about mnemonics methods is one of the important indicators, however also important is popularity due to the uses. According to this issue, authoritative question is "Which method/methods most often do you use?". The results of given question are presented in Figure 5.

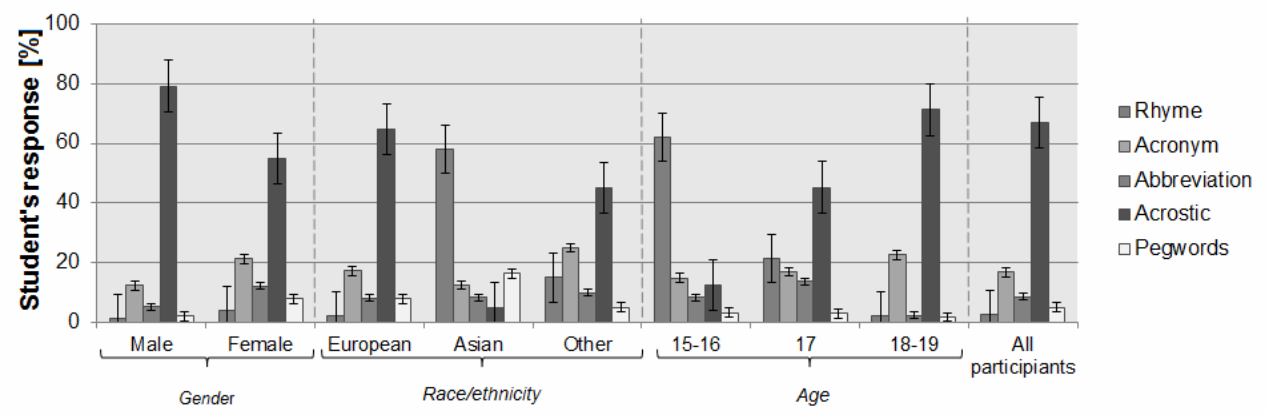

Fig. 5. The student's response of question 5 (Which method/methods most often do you use) from questionnaire in experiment 1 by gender, race/ethnicity, age and from point of all participants

Presented results shown that the most of participants $(67 \%$ according to all participants) pointed as the most popular - Acrostic method. This method is also very popular according to gender (male $-79.2 \%$, female - 54.8\%). However, this observation is quite different according to the ethnicity. For European this method is most popular $(64.8 \%)$, but for Asian is on the last position in the ranking of the popularity (4.9\%), on the first place is Rhyme method. However, for other nationalities this method is the most popular $(45 \%)$. Very interesting the dependence is observed according to age of participants - the popularity of Acrostic method is increases together with the age. This correlation can be explained according to three facts: 1) in following stages of the education more and more often appears this method; 2) this method is most often used by students; 3 ) there exist a lot of examples in related literature.

The second place in ranking of popularity according to all participants is Acronym method. This observation has also good correlation according gender (male $-12.3 \%$, female - $21.3 \%$ ), however this method is more popular in female than male. Due to the nationality, for European and for other nationalities, this method is still on second place - but for Asian 
on second place is Pegwords method. According to age, on the second place is also Acronym method, moreover the popularity of this method is increases together with the age.

\section{How often Polish students use mnemonic methods during the learning}

The next important question due to the usefulness of mnemonics methods is - how often students use mnemonic methods during the learning? The results of this question are presented in Figure 6.

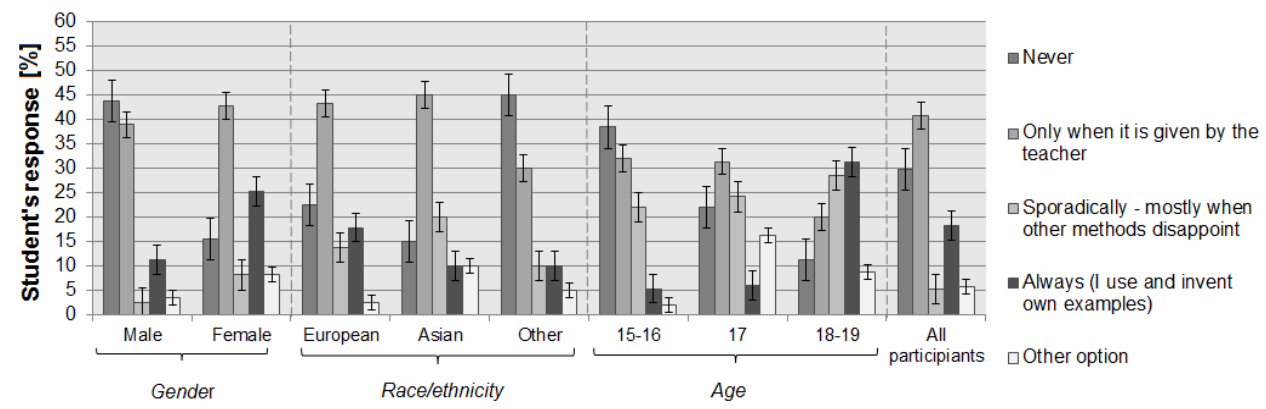

Fig. 6. The student's response of question 6 (How often do you use mnemonic methods during the learning?) from questionnaire in experiment 1 by gender, race/ethnicity, age and from point of all participants

These results indicate that most of male (43.8\%) never uses mnemonic methods during learning, moreover similar amount of male uses mnemonics devices only when it is given by the teacher $(38.9 \%)$. Only $11.3 \%$ of male uses always and invite their own mnemonic devises. Small amount of participants sporadically uses these methods when other methods disappoint $(2.5 \%)$ and similar amount of male pointed other option $(3.5 \%)$.

The different situation can be observed according to results of female - most of them only use mnemonics methods when it is given by the teacher $(42.7 \%)$ but one-fourth of male always uses and invite their own examples (25.3\%). On the other hand - 15.6\% never use these methods, and $8.2 \%$ of female admits that uses these methods sporadically. $8.2 \%$ of female pointed other option $(3.5 \%)$.

Big divergences in results can be observed due to the nationality. In European ethnicity most of participants $(43.2 \%)$ uses mnemonics methods only when it is given by teacher. Approximately amount of European admit that they never uses mnemonics method $(22.6 \%)$ or always they uses and invited their own examples (17.9\%). 13.8\% of participants pointed that they uses sporadically - mostly when other methods disappoint. Very small part of European ethnicity chose other option $(2.5 \%)$. Very similar response can be observed according to Asian nationality, however big differences are in other nationality/races. Most of other race $(45 \%)$ pointed that they never use mnemonics methods, and big part of these participants $(30 \%)$ uses these methods only when is given by teacher. Only $10 \%$ uses always these methods and these same amounts of participant's uses sporadically, mostly when other methods disappoint.

Interesting results can be observed also according to age of participants. Most of 15-16 years old participants never use mnemonic devices (38.4\%) and also only when it is used by the teacher $(32.1 \%)$. In this age of participants, the big part use mnemonics methods 
sporadically - mostly when other methods disappoint (22.1\%). Only $17.9 \%$ of $15-16$ years old students always use and invited their own examples. According to participants at 17 years old, the results are different. Most of this group pointed that they only use mnemonics studies when it is given by the teacher $(31.4 \%)$, on the other hand they also use sporadically - mostly when other methods disappoint (24.2\%). Similar amount of participants indicate that they never use mnemonic devices $(22.1 \%)$. Very small group of students always use and invite own examples $(6.1 \%)$. Generally, in according to 18-19 years old students, situation is inverse due to the 15-16 years students.

On which subject did Polish students use examples which can be a mnemonics device?

The results of application of mnemonics devices according to subjects in Polish schools are presented in Figure 7.

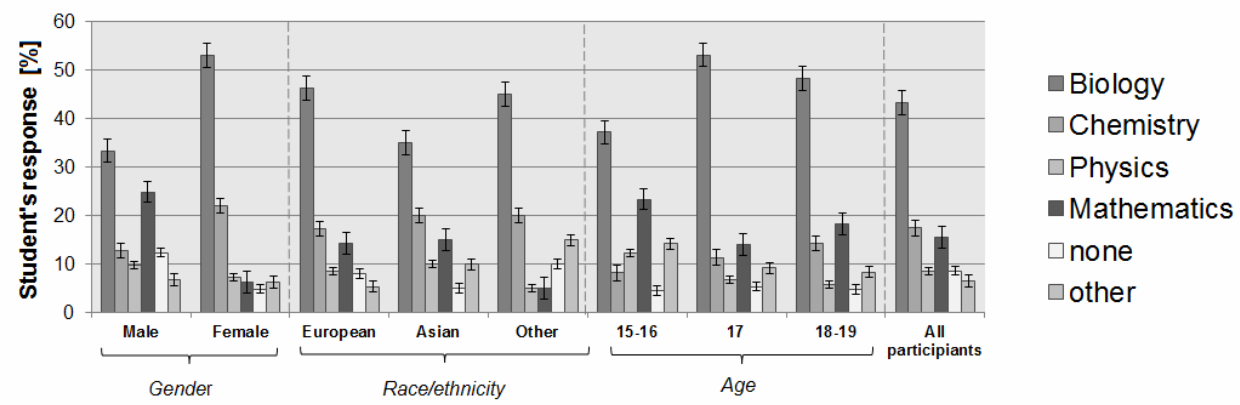

Fig. 7. The student's response of question 6 (On which subject did you use examples which can be a mnemonics device?) from questionnaire in experiment 1 by gender, race/ethnicity, age and from point of all participants

The results of question 6. Due to the gender are unexpected enough. For male and also female the most pointed subject is biology, but it is not clear why results are so scattered (male - 33.4\%, female - 53\%). Another different is second place - for male it is mathematics $(24.9 \%)$, but for female is chemistry $(22.1 \%)$. The physics is on third place according to female $(7.4 \%)$, but for male on the third place is chemistry $(12.8 \%)$. These differences could be explained by differences in memory according to female and male.

Due to the ethnicity, the most popular is biology (European $-46.3 \%$, Asian $-35 \%$ and other nationalities - 45\%), the second is chemistry (European - 17.3\%, Asian - $20 \%$ and other nationalities $-20 \%$ ) and the third place is mathematics for European (14.4\%) and for Asian (15\%), however for other nationalities are other subjects (15\%).

According to age, the results are very similar for all groups - the first place is biology (15-16: $37.2 \%$; 17 : $53.1 \%$; and for 18-19: 48.3\%), the second place is mathematics (15-16: $23.4 \% ; 17: 14.1 \%$; and for $18-19: 18.3 \%$ ).

Most of students indicate as other subjects - history (43.7\%), geography (22.3\%) and music/art (18.4\%), Polish language (10.4\%). 


\section{Conclusions}

Why mnemonics devices are effective? From a cognitive perspective, mnemonic strategies are effective because they form an effective acoustic-imaginal link between the stimulus and response. As didactic tool, they are extremely effective in helping pupils to remember things, however there is a lack of relationship between the conceptual content and the material being learned. What is interesting is that, the educational research indicate that, the own prepared mnemonics by students outperform the results in comparison to students in free-study conditions, but also students' performances may be lower than when teachers supply the strategies. In most cases among Polish pupils, they known a lot of examples of mnemonics studies in chemistry, biology, physics and mathematics, however they don't know what kind of this method are. Due to the information point of view, mnemonics techniques often better enables information to be retained in memory, however they are focused only on certain aspects of their operation and they are not dependent as a memory schema. And at last - mnemonics devices are memory strategies but they are not a teaching and learning methods, they can be only considered as didactics tools.

\section{Acknowledgments}

This article was made by the support of Anna Jurowska scholarship by the Marian Smoluchowski Kraków Research Consortium "Matter-Energy-Future" granted the status of a Leading National Research Centre (KNOW) at Faculty of Chemistry Jagiellonian University in Kraków.

The Authors wish to express their thanks also to the all teachers and all students from the Upper Secondary Schools in Warszawa, which wants to be anonymous.

\section{References}

[1] Guthrie J, Encyclopedia of Education. New York: Macmillan Reference; 2002; 1669-1672.

[2] Mastropieri M, Scruggs T. Enhancing school success with mnemonic strategies. Intervention School Clinic. 1998;33:201-209. DOI: 10.1177/10534512980 3300402.

[3] Bellezza F. Mnemonic devices classification, characteristics, and criteria. Rev Educational Res. 1981;51:247-275. DOI: 10.3102/00346543051002247.

[4] Ericsson KA, Kintsch W. Long-term working memory. Psychol Rev. 1995;102:211-245. DOI: 10.1037/0033-295X.102.2.211.

[5] Ericsson K. Exceptional memorizers: made, not born. Trends Cognitive Sci. 2003;7(6):233-235. DOI: 10.1016/S1364-6613(03)00103-7.

[6] Robertson-Tchabo E, Hausman C. A classical mnemonic for older learners: a trip that works! Educational Gerontol. 1976;1:215-226. DOI: 10.1080/0360127760010301.

[7] Kessels R, De Haan E. Mnemonic strategies in older people: a comparison of errorless and errorful learning. Age Ageing. 2003;32:529-533. DOI: 10.1093/ ageing/afg068.

[8] Gruneberg M, Monks J, Sykes R. The first letter mnemonic aid. Medical Sci: and Psychiatry: Social Occupational Medicine. 1977;5:304-308.

[9] Scruggs T, Mastropieri M, McLoone B, Levin J, Morrison C. Mnemonic facilitation of learning disabled students' memory for expository prose. J Educational Psychol. 1987;79:27-34. DOI: 10.1037/0022-0663.79.1.27.

[10] Mastropieri MA, Scruggs T, Fulk B. Teaching abstract vocabulary with the keyword method: Effects on recall and comprehension. J Learning Disabilities. 1990;23:92-96. DOI: 10.1177/002221949002300203.

[11] Scruggs T, Mastropieri M. Classroom applications ot mnemonic instruction: Acquisition, maintenance, and generalization. Exceptional Children. 1992;58:219-229. DOI: 10.1177/001440299105800305.

[12] Kilpatrick J. Doing mathematics without understanding it: A commentary on Higbee and Kunihira. Educational Psychol Rev. 1985;20:65-68. DOI: 10.1207/ s15326985ep2002_2. 


\title{
BADANIA PILOTAŻOWE O WIEDZY I STOSOWANIU MNEMONIK Z PRZEDMIOTÓW ŚCISŁYCH PRZEZ POLSKICH UCZNIÓW
}

\author{
Wydział Chemii, Uniwersytet Jagielloński w Krakowie
}

\begin{abstract}
Abstrakt: Strategie mnemoniczne to specyficzne sposoby, które podczas kodowania nowej informacji wykorzystują znane już elementy do polepszenia późniejszego dostępu do tej informacji w pamięci. Strategie te mogą często wspomagać uczenie się oraz późniejsze przywoływanie informacji. Jednak niewiele wiadomo na temat technik optymalizowania przywoływania myśli za pomocą metod mnemotechnicznych lub stosowalności metod mnemotechnicznych w praktyce edukacyjnej. Ponadto, w literaturze jest wiele przykładów metod i podejść mnemotechnicznych w chemii, biologii, fizyce czy matematyce, jednakże w literaturze fachowej brak jest aktualnych i miarodajnych badań na ten temat. Artykuł ten stanowi autorskie podejście do zagadnienia metod mnemotechnicznych z punktu widzenia uczenia i nauczania przedmiotów przyrodniczo-ścisłych. Dużym atutem artykułu jest demonstracja starych i dobrze znanych metod uczenia/nauczania w nowym wymiarze. Zgodnie $\mathrm{z}$ naszą wiedzą jest to pierwszy artykuł $\mathrm{w}$ literaturze opisujący aktualne dane na temat związany $\mathrm{z}$ uczeniem i studiowaniem przedmiotów ścisłych przy użyciu metod mnemotechnicznych.
\end{abstract}

Słowa kluczowe: mnemonika, metody mnemotechniczne, metody mnemoniczne, metody zapamiętywania, przedmioty przyrodniczo-ścisłe 